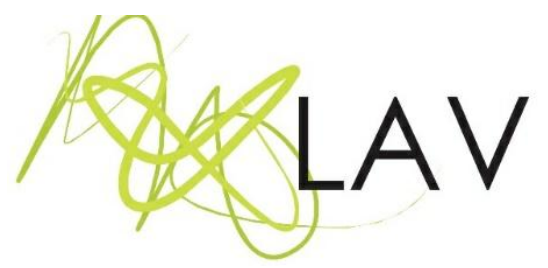

\title{
O cinema abrindo alas para as aprendências no cotidiano escolar
}

Cinema making way for learning in school daily life

Sandra Kretli da Silvai Universidade Federal do Espírito Santo

Ana Cláudia Santiago Zouain ${ }^{\mathrm{ii}}$ Universidade Federal do Espírito Santo

Nathan Moretto Guzzo Fernandesiii Universidade Federal do Espírito Santo

\section{Resumo}

Este artigo problematiza a força das imagens cinematográficas em diferentes experiências de pesquisas realizadas em Vitória - ES. O primeiro movimento trata de pesquisas junto às crianças e professoras de Educação Infantil que, no encontro com as imagens cinema, produzem imagens de pensamentos, abrindo o campo dos possíveis para a composição de diferentes imagens-escola por meio do devir-criança inventivo. Já o segundo movimento apresenta como as ações criadas no cineclube Valente, localizado em uma Escola Estadual de Ensino Médio, fazem movimentar o currículo e os processos de aprenderensinar. Como metodologia, usa as redes de conversações nas quais indivíduos e grupos colocam-se em relação na produção de conhecimentos, saberes e afetos movidos pelos agenciamentos de formas/forças comunitárias, objetivando a expansão da potência de ação coletiva. Por fim, conclui que os movimentos de pesquisa com imagens-cinema em redes de conversações constituem-se como espaços de criação coletiva, na composição de outros possíveis para as escolas.

Palavras-chave: imagens cinematográficas, redes de conversações, movimentos inventivos curriculares.

\begin{abstract}
The present article problematizes the strength of cinematographic images in different research experiences carried out in Vitória - ES. The first movement deals with research about children and teachers of Early Childhood Education, who, in the encounter with cinema images, produce images of thoughts, opening the field of possibilities for the composition of different school images through the becoming-inventive child. The second movement, on the other hand, shows how the actions created in the Valente film club, located in a State High School, move the curriculum and the processes of learning. It is employed, as a methodology, the networks of conversations in which individuals and groups place themselves in relation to the production of knowledge, learning and affections moved by the assemblages of community forms/forces, aiming at the expansion of the collective action potency. It is concluded that the research movements with cinema-images in conversation networks are spaces of collective creation, in the composition of others possible for schools.
\end{abstract}

Keywords: cinematographic images, conversation networks, curriculum inventive movements. 


\section{O cinema abrindo alas para as aprendências e os afetos no cotidiano escolar}

Ô abre alas que eu quero passar

Ô abre alas que eu quero passar

Eu sou da lira Não posso negar Ô abre alas Que eu quero passar (Chiquinha Gonzaga)

A musicista Chiquinha Gonzaga ${ }^{1}$ fez ecoar esse canto por muitos e muitos anos em diversos carnavais, abrindo alas para momentos de alegria ao povo brasileiro. Por entre corredores, movimentos intensivos, corpos, imagens, crianças, jovens, professores e professoras, rotina e invenção, adentramos as escolas com a força do abre alas, buscando atravessar nos fluxos dos devires, dos agenciamentos e dos encontros com as imagenscinema e capturar afetos que potencializam as aprendizagens nos cotidianos escolares.

Nossos corpos trouxeram consigo imagens-lembrança (BERGSON, 2006) que foram armazenadas de outros encontros com os cotidianos escolares nos quais atuamos como alunas, professoras, pesquisadoras ${ }^{2}$. Imagens rotineiras, fixadas na memória, que nos levam a uma reprodução habitual por meio de imagens-ação (DELEUZE, 2007). Essas imagens ainda encontraram outras produzidas externamente, que movimentaram nossos corpos em imagens-percepção (BERGSON, 2006). Nesse processo de afetação dos corpos, experimentamos imagens que duraram e perduraram nos sentidos, intensificando-se em imagens-afecção (DELEUZE, 2007) que nos interessam nesse movimento de escrita.

A partir das contribuições de Deleuze (2007, p. 170), problematizamos o que resta desses encontros com as imagens-cinema em processos de formação inventiva em redes de conversações. "[...] Restam os corpos, que são forças, nada mais que forças. Mas a força já não se reporta a um centro, tampouco enfrenta um meio ou obstáculos. Ela só enfrenta outras forças, refere-se a outras forças, que ela afeta e que a afetam".

Para Bergson (2006), o universo material é composto por imagens. E, se tudo são imagens, logo, nosso corpo-pensamento é constituído por elas. Somos atravessados por imagens-forças e forças-imagens. Imagens de todos os tipos, reais e virtuais. Imagensmovimento e imagens-tempo. Imagens orgânicas e imagens cristais, que configuram o nosso corpo em devir.

\footnotetext{
${ }^{1}$ Chiquinha Gonzaga foi a promotora do encontro do carnaval com a música para se tornar o grande espetáculo da nacionalidade brasileira. Foi com a música ó abre alas que o carnaval se consagra como festa popular.

${ }^{2} \mathrm{O}$ uso dessas palavras apenas no feminino objetiva homenagear as mulheres da educação brasileira que, em sua maioria, pensam e fazem as escolas todos os dias por meio das múltiplas relações que estabelecem com todos os aparatos culturais que circulam nos seus cotidianos.
} 
Deleuze (2007) nos diz que na vida tudo é questão de forças. Quando adentramos os cotidianos escolares e nos envolvemos em meio às redes de conversações (CARVALHO, 2009) com os praticantes daqueles espaços-tempos, mobilizamos forças e somos mobilizados por forças que passam a habitar nossos corpos. Forças-imagens que agem e reagem umas sobre as outras. Nesse sentido, nossos corpos são forças que se entrecruzam com outras forças. Em busca desse desejo de nos afetar e sermos afetados, bem como de expandir a potência de ação coletiva, o presente texto-imagem se compõe com as relações de forças produzidas com crianças, jovens e professoras no encontro com diferentes imagens cinematográficas, na tentativa de disparar afetos e afecções que impulsionam a criação de outras/novas imagens de escola possíveis.

Portanto, nesse duplo de imagens reais e imaginárias, verdadeiras e falsificantes, habitamos um corpo atravessado por imagens diversas. Um corpo múltiplo, rizomático e pulsante que se lança aos movimentos provocados pelas imagens. Imagens cinema, imagens escola e imagens de vida, na composição de um corpo-força-coletivo que se encontra com o outro do pensamento, que afeta e é afetado nas relações estabelecidas.

Assim, o presente artigo objetiva problematizar a força das imagens cinematográficas com crianças, jovens e professoras, argumentando que o encontro com as imagens cinema, em redes de conversações, força o pensamento, impulsionando o corpo-coletivo a problematizar os processos de aprendizagem-ensino e a criar movimentos aberrantes que impulsionam as invenções curriculares ${ }^{3}$. Sua justificativa se tece em meio às tentativas de centralização curricular de modelizar e padronizar as escolas, as professoras, as crianças e os jovens, apostando que os encontros com as imagens em processos formativos possibilitam movimentos aberrantes que provocam uma ruptura nos mecanismos de aprisionamento, abrindo alas para os devires e linhas de fuga para a expansão dos processos de aprendizagens e de criação coletiva.

A partir da discussão em torno dos conceitos de imagem-cinema, movimentos aberrantes e pensamento nômade, este artigo dialoga com Bergson (1979, 2006), Deleuze (2007, 2010), e Deleuze e Guattari (1997, 2000). Toma como aporte teórico-metodológico as redes de conversações entre praticantes dos cotidianos escolares, apostando na capacidade de indivíduos e grupos colocarem-se em relação para produzirem e trocarem conhecimentos, saberes e afetos movidos pelos agenciamentos de formas/forças comunitárias, objetivando a expansão da potência de ação coletiva (CARVALHO, 2009). Nesse contexto, o campo problemático deste texto se constitui pelo seguinte questionamento: Que potências as imagens cinematográficas produzem na construção

${ }^{3}$ Trata de pesquisas que se entrecruzam e dialogam com o projeto de pesquisa e de extensão, Filmes e conversas: por uma estética dos encontros, que teve início em 2013 e permanece em andamento com a força de outros signos da arte.

Revista Digital do LAV - Santa Maria - vol. 14, n. 2, p. 229 - 246 - mai./ago. 2021 ISSN 1983 - 7348 http://dx.doi.org/10.5902/1983734865040 
coletiva de outros possíveis para os processos aprendentes e os movimentos curriculares inventivos?

Vale ressaltar que as cartografias dos movimentos de pesquisa com as imagens cinematográficas em redes de conversações constituem-se como espaços de trocas de experiências e de criação coletiva, pois as conversas desenvolvidas pelas afecções das imagens mobilizam o pensamento, fazendo o corpo-coletivo pulsar e vibrar. Assim, abrem alas para uma multiplicidade de devires, afetos, saberes, linguagens e culturas circularem, provocando novos movimentos curriculares e outros possíveis para as escolas. Para caminhar nessa discussão, apresentaremos alguns movimentos de nossas experiências de pesquisa em diálogo com pensamentos de outros pesquisadores, na tentativa de afirmar a escola como um lugar de vida intensiva, inventiva e nômade.

Este artigo está dividido em três grandes movimentos. Em "Movimento um: cartografias de encontros com crianças e professoras da Educação Infantil e imagens cinema", trata de pesquisas junto às crianças e professoras de Educação Infantil que, no encontro com as imagens cinema, produzem diferentes imagens de pensamentos, abrindo o campo dos possíveis para a composição de novas imagens escola por meio do devircriança inventivo (DELEUZE; GUATTARI, 1997). Em "Movimento dois: cartografias de um encontro com jovens e adolescentes e imagens-cinema", busca capturar os efeitos das ações criadas no cineclube Valente, localizado em uma Escola Estadual de Ensino Médio do município de Vitória, ES, problematizando que forças fazem movimentar o currículo e os processos de aprenderensinar na escola. Por fim, trazemos "Movimentos in-conclusivos" não para fechar a discussão, mas como uma pausa para retomar alguns questionamentos e para se pensar nos movimentos diversos que se tecem no encontro entre imagenscinema e Educação.

\section{Movimento um: cartografias de encontros com crianças e professoras de Educação Infantil e imagens-cinema}

Acreditamos com Rolnik (2018, p. 29) que "[...] uma atmosfera sinistra envolve o planeta. Saturado de partículas tóxicas do regime colonial-capitalístico, o ar ambiente nos sufoca". Ao se apropriar da vida dos indivíduos, tenta aprisioná-los. Esse ar que nos sufoca tem se espalhado densamente com a força de uma imagem dogmática do pensamento que emoldura a educação brasileira. Essa imagem, além de ditar os interesses curriculares dominantes, legitima uma maneira de aprender em detrimento das demais, distanciando assim, de novos processos de subjetivação e de outras possibilidades de criação. 
No entanto, em meio às linhas duras, linhas flexíveis também compõem o plano de imanência da escola, e a estas mobilizamos nosso desejo de escrita, pois, por meio delas, fomos afetados, sendo impossível pensar em uma única imagem idealizada de educação, mas em imagens outras possíveis de inventividades na/da escola. Buscamos, assim, por meio do encontro das crianças e das professoras com os signos artísticos do cinema, driblar a imagem dominante fixada tanto nos processos curriculares instituídos quanto nos processos aprendentes, para pensar a complexidade de acontecimentos inventivos e de vida que vibram na escola movidos pelos afetos, compreendendo que há um 'corpo-vibrátil' ou 'corpo-pulsional' que se constitui e se orienta por uma "prolífera vida, vida singular, uma vida" (ROLNIK, 2018, p. 65). Para tanto, trazemos cartografias ${ }^{4}$ de nossas imagens de pesquisa para afirmar a aposta na potência das imagens-cinema enquanto forças que movimentam os pensamentos de crianças e professores em devires outros.

"Eba! Hoje tem cinema", vibrava uma criança enquanto nos preparávamos para ir à sala de vídeo. Já estávamos inseridos nas redes de conversações antes mesmo de o filme começar. Corpos atentos, curiosos, inquietos, entravam em composição com as redes afetivas que iam se tecendo junto aos movimentos aberrantes que abrem alas para os devires passarem. Os encontros das crianças e das professoras com as imagens-cinema não se reduziam apenas aos momentos de exibição e de conversas na sala de vídeo, mas eram eternizados nos corpos-pensamentos, pois as imagens-afecções que deslizavam por entre imagens-cinema e imagens-escola na composição de cenas de vida intensiva e inventiva.

Por entre curtas-metragens, filmes de animação, elaboração de roteiros, produções de imagens fílmicas, as crianças e professoras percorriam com a câmera do desejo, em corpos-coletivos vibráteis, abrindo alas para o devir-criança fabular e inventar outras imagens para as infâncias, para os processos de aprenderensinar e para os currículos.

Emergiram movimentos aberrantes e inventivos em meio às afetações dos corpos com a força das imagens cinematográficas. Essa força era impulsionada pela potência das imagens que distanciava os corpos orgânicos de um regime fechado e veraz, mobilizando imagens por meio de movimentos falsificados de corpos que se abriram ao campo dos possíveis e para a força dos encontros com as imagens. Forças que se expandiram na rede de conversações, fazendo pulsar a vida emergente "[...] que sabe se transformar, metamorfosear-se de acordo com as forças que encontra, e que compõe com elas uma

\footnotetext{
${ }^{4}$ Os encontros com as crianças e professoras ocorriam, semanalmente, em processos formativos. Utilizamos curtas-metragens e filmes de animação como disparadores de redes de conversações para pensar e fabular novas imagens de escolas e expandir as aprendências e as invenções curriculares. As experimentações foram registradas em diários de bordo, arquivos fotográficos e vídeográficos.
} 
potência sempre maior, aumentando sempre a potência de viver, abrindo sempre novas possibilidades" (DELEUZE, 2007, p. 173).

Ao nos aproximarmos dos encontros com os signos artísticos do cinema, deslocamos diferentes imagens-escola, possibilitando-as ir além de uma imagem habitual e dogmática que tenta endurecer nossos corpos em uma ação preestabelecida. Assim, somos movidos por nossos impulsos criadores a fabular, a entrar em composição com um devir-criança inventivo e a viver intensamente os movimentos por meio da potência criadora da infância.

Nesse sentido, a professora fábula uma nova imagem para o Dia das Mães na escola: "[...] Eu estou super incomodada com esse tal de Dia das Mães", desabafa uma professora em uma das redes de conversas movida pelas afecções das imagens-cinema: "[...] Já problematizamos esse currículo movido por datas comemorativas. Desculpem-me, mas eu me recuso a parar o que estou fazendo com as crianças, para produzir cartão de Dia das Mães!".

A professora questiona por que temos tantas dificuldades para se permitir a experimentar outras linhas, a apostar nas linhas de fuga, nas linhas de vida intensiva e inventiva que se movimentam pelos afetos e afecções cotidianas. Ressalta que está com um projeto com as crianças denominado Invencionices infantis e que todos os dias as crianças produzem coisas extraordinárias, por isso não precisaria parar para confeccionar cartões: "[...] Eu gostaria mesmo era de expor as invencionices das crianças e mostrar as suas aprendizagens e que os pais reconhecessem e valorizassem a potência desses processos inventivos criados com as crianças", destaca a professora.

As crianças compõem todos os dias novas imagens para as escolas. Em alguns momentos, as professoras entram em composição e acompanham as linhas de fuga de seus alunos, dando brechas para o devir-criança habitar o corpo-escola. Ao mesmo tempo em que são capturadas pelas políticas de avaliação ou pelas diretrizes curriculares centralizadoras, deixam o corpo deslizar entre as peraltagens e fabulações infantis como aponta Carvalho e Leite (2018, p. 398):

Ora, a infância e suas imagens, juntamente com aquilo que nela e por ela deriva em múltiplas formas, acenam-nos para uma efetiva política inventiva que, escapando das normativas e das disposições gerais, criam campos de experiências que vazam por micro-poros; apresentam virtualidades estéticas impensáveis. 
O encontro com as imagens cinematográficas do curta Carregando as baterias ${ }^{5}$ em redes de conversações com as professoras de Educação Infantil possibilitou pensar as relações cotidianas:

[...] Este curta-metragem me faz lembrar uma imagem que me marcou no encontro passado. Percebi em uma das cenas em que aparece o robô que compraram para cuidar da velhinha, que lá no fundo havia uma cadeira vazia. Como aquela cadeira vazia, pequena, desfocada, me impactou, me afetou! Remete-me uma ausência, ausência de nós mesmos. A gente fica se enrolando com tanta coisa que dizem para nós fazermos e, assim, estamos interagindo cada vez menos. Lembro, também, de uma reportagem de um senhor que vendia picolé em frente a uma escola há mais de trinta anos que se emocionou ao aprender a ler. Uma aluna se sensibilizou ao perceber que o amigo era analfabeto e resolveu ensiná-lo. Eu fiquei querendo entrar nesse movimento da aluna. Estamos com a bateria muito baixa como no filme. As crianças se esforçam para expandir a nossa vibração. Estamos como bolhas circulando sem conseguir se conectar.

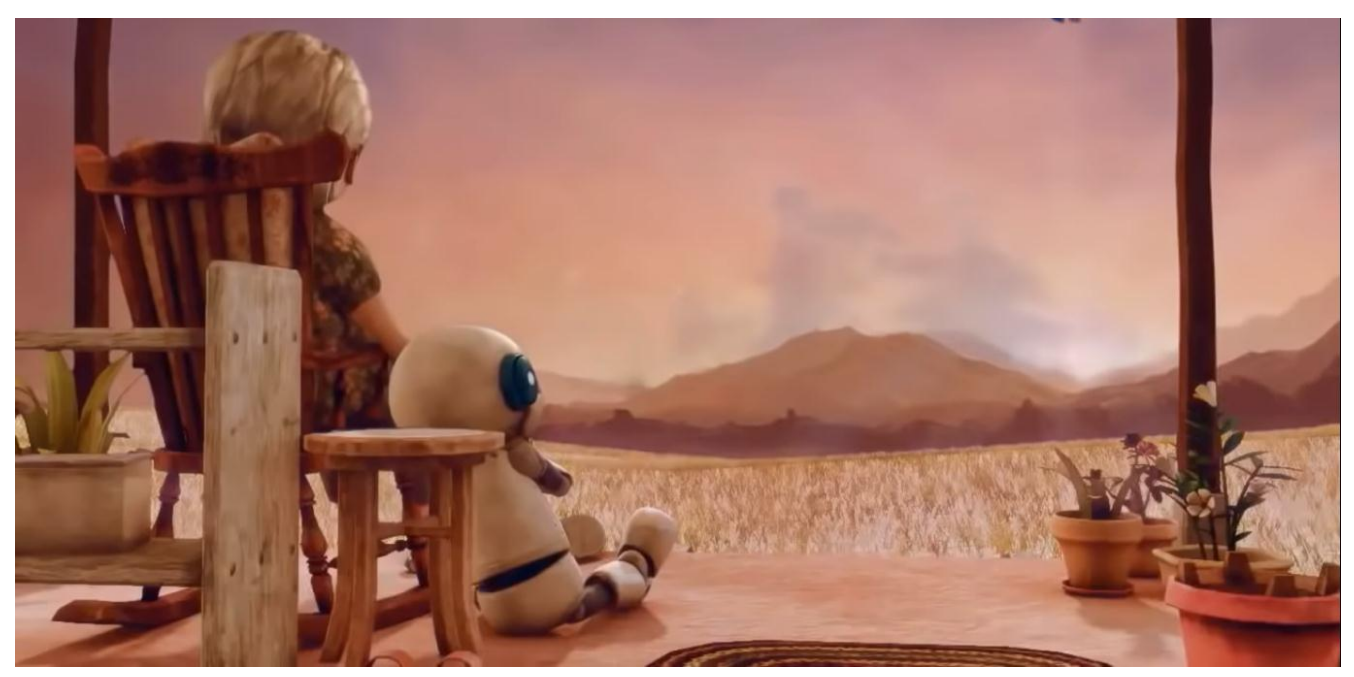

Figura 1: Cena do curta-metragem Carregando as baterias. Fonte: https://www.youtube.com/watch?v=j_KT_c22fiU

Dessa narrativa que emerge a partir das imagens de uma animação, nasce uma composição que se constitui "[...] nos fluxos intensivos engendrados nas linhas de vida, que produzem subjetivações desejantes, singularidades nômades: máquinas de fazer delírio com a intensidade da vida" (CARVALHO; SILVA; DELBONI, 2016, p. 218). Assim, emergem delírios e com eles novas problematizações: Como estão os nossos corpos? Que efeitos ${ }^{6}$ as imagens provocam no corpo-escola? O que faz expandir a força vibrátil inventiva da escola?

\footnotetext{
${ }^{5}$ Disponível em: https://www.youtube.com/watch?v=j_KT_c22fiU.

${ }^{6}$ Entendemos efeitos como produções coletivas em devir.
} 
As professoras apontam que são as invenções cotidianas que expandem a potência de ação coletiva e que são os encontros com as crianças que as revigoram. Ademais, ressaltam que as conversas com as famílias quando buscam a escola para compartilhar as experiências vivenciadas com os filhos, também, são afetos alegres que expandem a potência de ação coletiva. Destacam que se faz necessário apostar e acreditar nas experiências cotidianas tecidas com as crianças.

Como afirma Carvalho (2012, p. 8): "[...] nas crianças, pode-se melhor observar o devir manifestando-se num único e mesmo plano da vida". As crianças pensam em devir. Devir-outro. Devir-criança. Habitam um tempo aiônico, tempo intensivo, inventivo. Tempo-duração. Deslocam pensamentos. Função de fabulação. Circuito de imagem realimaginário. Imagens atuais e virtuais que se misturam e se confundem.

A fabulação, no entanto, diferencia-se da imaginação, pois "[...] a fabulação criadora nada tem a ver com uma lembrança mesmo amplificada, nem com um fantasma. Com efeito, o artista, entre eles o romancista, excede os estados perceptivos e as passagens afetivas do vivido" (DELEUZE, GUATTARI, 2000, p. 222). Ao fabular, as crianças e as professoras entram em um tempo outro, deslocam os sentidos e produzem diferentes imagens.

Apostamos, então, no encontro com imagens-cinema e imagens-escola na composição de imagens-infância que desterritorializa os territórios escolares, imagens que se configuram como "laboratórios ensaísticos de uma micropolítica estética sem pretensão de convencimento, porque o registro produtivo de suas imagens é da consistência do devirinfância" (CARVALHO; LEITE, 2018, p. 398).

Na figura 2, movida pelas afecções das imagens-cinema, uma criança desobedece à regra da professora de assistir ao filme sentado, ela se levanta e fala sobre o que as imagens deram a pensar. As que seguem a norma pedem silêncio: "[...] quero ouvir!", "Shiu!". A professora coloca a criança de volta ao seu lugar. A criança levanta-se novamente. 


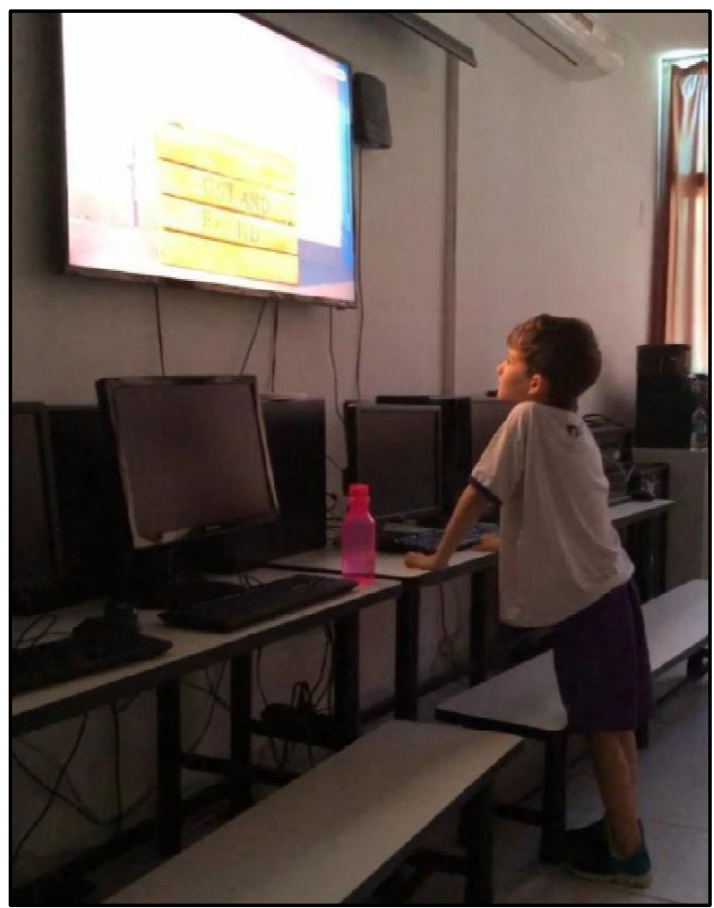

Figura 2: Um menino que não para... Fonte: ZOUAIN, 2019.

De modo geral, as crianças e as professoras, no encontro com as imagens-cinema, compõem diferentes imagens-escola que se distanciam de um movimento hierárquico e linear. A potência das imagens nos provoca a produzir movimentos aberrantes (DELEUZE, 2007) por uma educação não soberana. Movimentos que pensam a educação para além das lógicas normatizantes, que reproduzem uma imagem dogmática de pensamento, do currículo e da aprendizagem, mas que se lançam em prol de uma educação em devir, engendrada aos seus acontecimentos inventivos.

A potência dos signos artísticos nos move em meio às afecções que tocam nossos corpos e nos impulsionam a um agir impensado pela racionalidade modelizante, mas que passa a emergir em nossos corpos-pensamentos com as experimentações afetivas vivenciadas. Nesse sentido, as crianças e as professoras, movidas pelo devir-criança e impulsionadas com as imagens-cinema, insurgem, deslocam e fabulam imagens-escola para além de uma imagem petrificada que tenta aprisionar os corpos, vertendo-as em imagens impensadas, aberrantes e falsificantes, da ordem do acontecimento, compondo resistências que nunca deixam o corpo parar, mas o movimenta em constante devir.

Portanto, nesse movimento de afetação com imagens e com crianças, afrouxamos o arco sensório-motor habitual, deslocando práticas verticais de currículos e de docências, "por atos de criação de um corpo-pensamento em devir-devaneios" (ZOUAIN, 2019, p. 45). Somente um relaxamento dessa tensão, permite-nos ir além e, assim, colocamo-nos "de algum modo, na vida do sonho" (BERGSON, 2006, p. 180). Vida sonhada com crianças, 
professores, imagens-cinema e imagens-escola no entrecruzamento de forças que habitam os corpos e os permitem sonhar. Por entre potências de vida que se tecem no real e no imaginário, nas dobras da representação e da invenção, dando passagem para o deviralegria (CARVALHO, 2019) perdurar.

\section{Movimento dois: cartografias de um encontro com jovens e adolescentes e imagens-cinema}

Depois do Cineclube Valente eu não consigo mais assistir a um filme e não conversar. Eu preciso muito falar! (Estudante e cineclubista)

Como dito, o que nos interessa são os movimentos aberrantes, no sentido deleuziano do termo, daquilo que insurge dentro de um movimento e extrai dele novos fluxos e forças com intensidades para desalinhar o que está estabelecido, para perfurar o que se repete, possibilitando outras relações, dando abertura para novas composições.

Nesse sentido, segue nossa opção de acompanhar a potência de criação que habita os espaçostempos de um cineclube no cotidiano escolar que desde 2016 vêm utilizando as imagens-cinema como disparadoras de conversas e amplificadoras dos processos de aprenderensinar em uma escola pública de Vitória - ES. Em 2019, o projeto tem trabalhado com curtas-metragens produzidas no estado do Espírito Santo, por realizadores capixabas. Uma exibição que acompanhamos teve como temática o meio ambiente. Assim, problematizamos: o que pode o cinema na escola? Que redes são produzidas quando estamos organizados em cineclubes? Que conversas um filme pode disparar? Qual o potencial do cinema nos processos de aprenderensinar?

Deleuze (2007) faz um grande esforço para nos mostrar que há na imagemmovimento um outro tipo de movimento, que foge à centragem, à coordenação-seleção, à construção vertical, que é a aberração de movimento ou movimento aberrante. "Mas, longe de o próprio tempo ficar abalado, ele encontra nisso a ocasião de surgir diretamente, e de livrar-se da subordinação ao movimento, de reverter essa subordinação" (DELEUZE, 2007, p. 50), de apresentar o tempo como abertura infinita.

Nessa linha, afirmamos que o cineclube ${ }^{7}$ possui uma forma aberrante de exibição, porque não se limita a exibir filmes corriqueiros, hollywoodianos, clichês, para contemplação. Ao contrário, associam-se a filmes nacionais e locais que trazem outras

\footnotetext{
7 O cineclube que acompanhamos chama-se Cineclube Valente, é um projeto desenvolvido na E.E.E.M. Des. Carlos Xavier Paes Barreto, em Vitória - ES, composto por estudantes de $1^{\circ}, 2^{\circ}$ e $3^{\circ}$ ano do Ensino Médio e coordenado por uma professora. Eles organizam as mostras e de acordo com a temática, escolhem os curtas-metragens que serão exibidos, bem como o roteiro para as conversas. Todo o desenvolvimento é feito de maneira coletiva pelos integrantes e as exibições são para alunos da mesma escola.
} 
imagens, sons, paisagens, e se preocupam em buscar filmes que problematizam o contexto atual. Ao darem abertura para conversas após as exibições, engendram possibilidades de ampliar os efeitos provocados pelas imagens cinematográficas com as redes de conversações e seus atravessamentos. A partir de uma intencionalidade ético-política e estética, com a "forma-aberrante de exibição" (...) "criam-se exibições ativas que se prolongam pelas intensidades dos encontros-imagens-conversas" (FERNANDES, 2019, p. 102).

Quando pensamos na força das imagens cinematográficas no cotidiano escolar, apostamos que o cinema possui imenso potencial para colocar o pensamento em movimento. Assim, buscando imprimir alguns efeitos de um encontro no cineclube na escola, destacamos os agenciamentos reverberados a partir da exibição do curtametragem Rio das lágrimas secas.

O curta-metragem Rio das lágrimas secas, dirigido por Saskia Sá (2018), é um curta-documentário. Nele, a cineasta apresenta um recorte em três atos que, englobando três lugares diferentes, delineiam os efeitos catastróficos da lama em diferentes pontos do rio após o rompimento da barragem de rejeitos no desastre-crime promovido pela Samarco S.A., em corresponsabilidade com Vale S.A. e BHB Billiton, em novembro de 2015. Em três atos, a história passa por Mariana - Minas Gerais (MG), próximo ao epicentro do desmoronamento da lama; por Resplendor - MG, na aldeia Krenak, Uatu; e pela Vila de Regência - Linhares - ES, na foz do rio Doce.

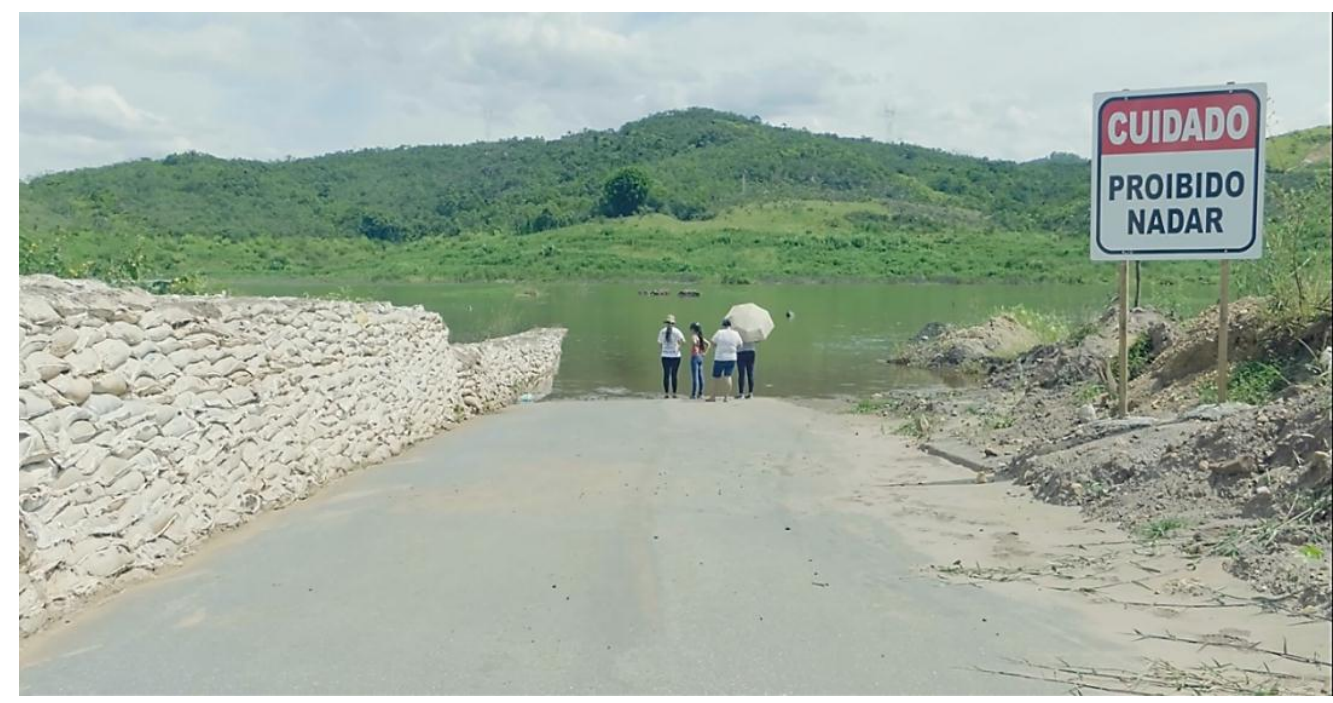

Figura 3: Cena 01 - Rio das lágrimas secas, dirigido por SaskiaSá. Fonte: https://vimeo.com/281859929.

${ }^{8}$ O filme ganhou o prêmio principal da $5^{a}$ Mostra Velho Chico de Cinema Ambiental. Venceu também a categoria Melhor Filme nas mostras Foco Capixaba e Cinema Ambiental, do $25^{\circ}$ Festival de Cinema de Vitória. 
Em todos os atos elencados, mulheres moradoras das comunidades atingidas, contam as histórias do que mudou com a chegada da lama, seus dramas e medos, expondo perdas que ultrapassam questões materiais, como as memórias de um lugar que não existe mais, a relação de vidas que são tecidas na relação com o Rio ou com o mar. As imagens do filme, feito nômades, viajam pelas paisagens, pelas culturas, pelas memórias das mulheres, pelas comunidades afetadas (FERNANDES, 2019).

O objetivo dos cineclubistas com essa exibição foi movimentar o pensamento em relação às questões relacionadas à poluição, ao desperdício de água, à produção de lixo, ao desperdício de alimento e ao excesso de consumo. Após a exibição, encaminhávamos para as conversas e o roteiro preparado pelos cineclubistas traziam algumas perguntas para intensificar o debate.

Logo de início, estudantes associaram as imagens de Rio das lágrimas secas à poluição da praia de Camburi, em Vitória: "[...] Tipo quando você vai na praia de Camburi, você olha e você vê o mar, aí quando você olha para a sua esquerda, você vê o fogo subindo, da Vale, poluindo o ar. Tem o pó de minério também, que aqui cai na praia, no filme, no rio".

Algumas questões foram apresentadas problematizando as nossas relações com o mundo: "[...] que práticas nós temos que levam ao desperdício de água?"; "o que pode ser feito a partir de pequenas atitudes, para conter a poluição no nosso bairro, na nossa cidade, da nossa escola?" Uma rede de conversas possibilitou aos estudantes e professores confrontarem as relações que eles desenvolvem na escola, no trabalho e nos vários espaçostempos em que transitam, com práticas que preservam ou não o meio ambiente e, ainda, que expandem a potência do corpo-coletivo, conforme mostramos nas falas a seguir:

- No meu serviço veio um monte de papel impresso errado, tive que jogar tudo fora, foi um saco de papel. Lá usam muito papel. Tem muito processo e é tudo descartado. Devíamos reutilizar.

- Na escola está difícil, o diretor não colabora.

- Você falou do diretor, mas também poderia partir de qualquer aluno.

- Igual eu vejo geral na hora do recreio, a pessoa sentada assim na frente de uma lixeira, e joga o papel no chão. Ou sai do portão, e tem uma lixeira do lado do portão, eles trazem aqui para fora e joga o plástico no chão. Ou seja, deveria tentar reutilizar ao máximo, igual garrafinha de água, sempre estar usando a mesma, porque não é algo que você precisa estar trocando sempre.

- Justamente, assim como ela falou, muitas vezes, que tem a sujeira é porque a gente vê o lixo no chão e a gente não pega, porque não 
foi a gente que jogou. Assim, a gente acaba sendo egoísta com a nossa escola, com nossa rua. Aí, quando chove e tem enchente, o bueiro enche, por causa desses motivos.

Em outro momento, nas conversas, apontamentos para possíveis soluções foram levantados, como disse uma estudante: "[...] a gente poderia reciclar algumas coisas e reutilizar algo que dá para usar de novo" ou "o lixo não é apenas um lixo. Ele pode ser considerado uma semente", afirma outro estudante.

Ao propor discutir o meio ambiente tendo como disparador as imagens-cinema, o cineclube acaba por abrir possibilidades para, em meio às redes de conversações, que imagens-lembranças sejam confrontadas, expandidas e atualizadas por novas imagensnarrativas. Em processos aprendentes que decorrem de um jogo coletivo, de convergências, confrontações, discordâncias, problematizações e, sobretudo, abertura e exposição para que, nesse jogo, fôssemos atravessados pelos múltiplos corposexperiências que compõem aquele cenário.

Mais adiante, a partir de uma pergunta acerca da importância dos nossos rios para nossa vida de forma individual e coletiva, os estudantes revelam conhecimentos que são atravessados pelas experiências de vida, pelas vivências nos espaçostempos que eles residem, mostrando que os processos de aprenderensinar extrapolam a escola, porque se constituem em redes de afetos e de afecções, a fim de inventar problemas e criar novos mundos. Outro jovem pede a palavra para com-partilhar a sua experiência de vida:

- No filme, a índia chora, porque não pode entrar no rio depois da lama. Eu já chorei, porque meus pais não deixam eu entrar na lagoa que tem perto da minha casa, pois está poluída... quem entrava pegava doença. Eu já vi um cano enorme que joga lixo lá dentro, ele foi colocado há pouco tempo, deve aumentar muito as bactérias no rio, por isso as doenças. Parece que o tempo passa, mas a mentalidade dos políticos volta pra trás.

- Eu tenho um tio que pesca. Antigamente ele fica ficava 20, 30 dias no mar, e agora ele fica 10 e volta. Está péssimo para pescar! Os portos e os barcos grandes estão acabando com os peixes.

- É o capitalismo!

- Mas no mangue está ruim também?

- Pelo jeito está bom, porque o preço do caranguejo está acessível. Quando está bem difícil o preço aumenta bastante.

Por vezes silenciadas pelos processos colonizadores de uma cultura-escola-currículo maior, tanto com os filmes quanto com as conversas, vimos imagens-enunciações que navegam por paisagens e culturas menores que proclamam como forças descoloniais outras formas de vida, de habitar e de saber. Apresentam-nos processos aprendentes que 
não se restringem à escola, visto que excedem a partir de suas experiências, a exemplo da estudante que nos conta sobre a relação da disponibilidade do caranguejo na natureza e o valor no comércio.

As imagens e as narrativas expressam saberes que são inseparáveis do conhecer, sentir, viver, habitar e experienciar, que se nutrem um do/no/com outro. Em um processo de constante antropofagia, encontram-se conhecimentos que extrapolam a escola, mas, também, retornam a ela nas matemáticas, geografias, biologias e nas possibilidades de intercâmbio com os contextos vividos pelos estudantes e professores. Aliás, uma proposta, uma atividade ou uma imagem que se produz delas, antes que prisioneiras das imposições podem ser sem fronteiras e circular por caminhos indefinidos, tendo a capacidade de afetar e ser afetada, criando outras imagens e outros movimentos de pensamentos.

Para que isso ocorra, é fundamental que haja o fortalecimento dos grupos, bandos escolares que afirmam outros modos de aprenderensinar e outros currículos no cotidiano escolar, para aumentar assim a "potência da ação coletiva", como afirma Carvalho (2011), pois essa potência depende de modo fundamental da capacidade dos grupos e indivíduos estabelecerem e criarem relações "para produzirem e trocarem conhecimentos, resultando, então, no agenciamento de formas/forças comunitárias, com vistas a melhorar os processos de aprendizagem e criação nas coletividades" (CARVALHO, 2011, p. 75).

É na coletividade que se inscreve esse currículo, desdobrando-se a partir dos encontros no cineclube, como corpo político. Muito embora a coletividade não deve ser entendida como homogeneidade ou espaço estriado, mas como "o aparecimento da pluralidade e da diferença que interrompem a mesmidade" (CARVALHO, 2011, p. 86), como máquina política - de guerra? Ademais, "que não diz o que é de modo universal ou o que deve ser, mas força a comunidade a se transformar e que faz seu devir sempre aberto e permeável, logo, sempre outro 'possível'" (CARVALHO, 2011, p. 86).

No caso da escola e dos currículos, esses tipos de filmes, atrelados à "formaaberrante de exibição" no cineclube, plantam elementos que podem molecularmente impulsionar agenciamentos coletivos de enunciação para pensar o impensável no cotidiano escolar, ver o que não é visto, sentir o que não é sentido, produzindo um transe a partir da quebra dos automatismos da imagem-pensamento. Indicam fugas das situações globalizantes nos modos de aprenderensinar, pois, em vez disso, optam por situações dispersivas, cotidianas. Há nesse sentido uma atitude claramente estética e ético-política na escolha dos filmes que serão exibidos, bem como das problematizações que serão lançadas no cineclube (FERNANDES, 2019).

Em um exercício inseparável da sua intencionalidade, intensifica a faculdade de ver, educando o olhar, onde as imagens possibilitam uma ruptura com o vínculo sensório-motor 
como unidade do movimento, trazendo novas forças deslocantes para as exibições. E "[...] educar o olhar é justamente permitir que ele seja sem educação, isto é, jamais passivo de ser tolhido na potência de seu alcance e na lucidez de sua singularidade" (CARVALHO; LEITE, 2018, p. 409).

"Como a aula passou rápido". Essa afirmação de uma professora nos sugere que há um tempo de intensidades que não pode ser apenas o tempo cronológico, linear ou sequencial. $O$ que temos experimentado muitas vezes, no encontro com as imagenscinema no cineclube, é abertura para tempos outros. É um tempo de experiências acontecimental que dá sovas nas formas rígidas de certas hierarquizações e controle dos tempos escolares. Um tempo preenchido por reticências, que mesmo sendo curto, a exemplo dos curtas-metragens, dura pelas intensidades que produz. Uma duração que esfolia nossa pele deixando o rastro dos seus efeitos no corpo, pois como assevera Bergson (1979, p. 49, grifos nossos): "a duração real é aquela que morde as coisas e nelas deixa a marca do seu dente".

\section{Movimentos in/conclusivos}

Não acreditamos ser possível concluir uma escrita que se pretende pensar e afirmar a vida em devir-criança. Devir é uma potência criadora, constituída por encontros afetivos e intensivos. Por isso, continuamos a nos perguntar: Que afetos foram suscitados nos encontros das crianças, jovens e professores com as imagens cinematográficas em redes de conversações nas Escolas Públicas Municipais e Estaduais do Espírito Santo? Acreditamos que muitos foram os afetos, pois apostamos que o cinema abre alas para os devires. Devires-crianças, devires revolucionários, devires...

A nossa cartografia buscou mapear afetos alegres que expandem a força coletiva. Claro que também nos deparamos com afetos tristes que reduzem a potência de agir de crianças, jovens e professoras, porém, logo que os afetos tristes emergiram, um fluxo de afirmação da vida também surgia, e, assim, agarramo-nos a essas forças vibrantes, revigorantes de vida.

Procuramos no encontro com as imagens-cinema não apenas falar sobre os filmes, mas, sobretudo, conversar e problematizar sobre os seus efeitos no nosso pensamento. Assim, buscamos nesses encontros com as imagens justo ideias, como bem explica Deleuze (2010, p. 55), ao falar sobre as perguntas de Godart em programas televisivos: "[...] próprio do devir-presente, é a gagueira nas ideias; isso só pode se exprimir na forma de questões, que de preferência fazem calar as respostas. Ou mostrar algo simples, que quebra todas as demonstrações". 
Nesse caso, poderíamos afirmar, com Silva e Delboni (2017, p. 63), sobre a potência da imagem-cinema nos encontros que estabelecemos com crianças, estudantes e professores para fazer a língua gaguejar em meio às redes de conversações. É necessário intensificar a "[...] gagueira da língua, gerando outros/novos modos de pensar, fazer e de viver os cotidianos das escolas, abrindo frestas para línguas menores, que possibilitem a problematização do território-escola".

A coletividade se fortalece em redes de conversações, produzindo um posicionamento político, marcado por experiências que desacomoda e abrem alas para os devires passarem. "[...] O plano de vida, o plano da imanência é atravessado por diferentes linhas, forças e formas, o que implica dizer que entrar em relação à escola é entrar em relação à vida" (SILVA; DELBONI, 2017, p. 71).

Acreditamos, portanto, que as imagens cinematográficas em redes de conversações com crianças, jovens e professoras, como aponta Machado (2009, p. 296) ao citar Deleuze, atuam "[...] como uma força de fora que se aprofunda (se creuse), nos fisga e atrai o de dentro". A força das afecções que emergem no encontro com as imagens possibilita a ruptura sensório-motora que leva a situações óticas e sonoras puras, fazendo com que os praticantes do cotidiano se deparem com o intolerável presente na banalidade cotidiana, como o exemplo do menino inquieto que não para diante das imagens-cinema e dos jovens que coletivamente tentam inventar melhores relações com o mundo.

Deleuze aponta que a relação do homem com o mundo só pode ser restabelecida pela fé na imanência. A relação do homem e do mundo é, portanto, o in-possível, o inpensável que precisa ser pensado e construído com os possíveis. Machado (2010, p. 288) alerta-nos: "[...] quanto menos o mundo é humano, mais cabe ao artista acreditar e fazer acreditar numa relação do homem com o mundo".

Os movimentos de pesquisa com as imagens cinematográficas em redes de conversações constituem-se como espaços de trocas de experiências e de criação coletiva, pois as conversas mobilizadas pelas afecções das imagens violentam o pensamento, fazendo circular uma multiplicidade de saberes e de culturas, que provocam uma aprendizagem movida pela rede de afetos, fazendo emergir novos movimentos curriculares e outros possíveis para as escolas. Nossas experiências com as imagens de cinema têm mostrado que professores e estudantes instigados por elas expressam sentimentos/pensamentos que expandem a força do coletivo nas redes de conversações. Compõe, desse modo, momentos intensivos-inventivos de formação que possibilitam múltiplas criações curriculares, tecidas em meio a uma grupalidade que se expande de maneira intempestiva, revolucionária, democrática, colaborativa, sensitiva, inventiva, e... 


\section{Referências}

BERGSON, H. A Evolução Criadora. Rio de Janeiro: Zahar, 1979.

BERGSON, H. Matéria e memória: ensaio sobre a relação do corpo com o espírito. São Paulo: Martins Fontes, 2006.

CARVALHO, A. F.; LEITE, C. D. P. Inventividade nas imagens errantes: micropolítica estética e devir-infância. In: RODRIGUES, A. C.; BERLE, S.; KOHAN, W. O. Filosofia e educação em errância: inventar escola, infâncias do pensar. Rio de Janeiro: NEFI, 2018. p. 397-411.

CARVALHO, J. M. O currículo como comunidade de afetos/afecções. Revista Teias, v. 13, n 27, p. 75-87, jan./abr. 2011. Disponível em: <https://www.epublicacoes.uerj.br/index.php/revistateias/article/view/24253>. Acesso em: 4 ago. 2019.

CARVALHO, J. M. Macro/Micropolítica, cotidiano escolar e constituição de um corpo coletivo em devir. Revista Educação Temática Digital. Campinas, SP, v. 21, n. 1, p. 47-62, jan./mar. 2019.

CARVALHO, J. M. Devir-docência potencializando a aprendizagem sem medo. XVI ENDIPE - Encontro Nacional de Didática e Práticas de Ensino. UNICAMP, Campinas, 2012.

CARVALHO, J. M. O cotidiano escolar como comunidade de afetos. Rio de Janeiro: DP\&A; Brasília, DF: CNPq, 2009.

CARVALHO, J. M.; SILVA, S. K.; DELBONI, T. M. Z. G. F. Movimentos de invenções curriculares no cotidiano escolar: a potência da imagem-cinema fazendo a língua pegar delírio. Momento, v. 25, n. 1, p. 205-220, jan./jun. 2016. Disponível em: <https://periodicos.furg.br/momento/article/view/6119/3934>. Acesso em: 19 nov. 2019.

DELEUZE, G. Imagem-Tempo. Tradução de Eloisa de Araújo Ribeiro. Brasiliense. 1. ed., [1985] 2007.

DELEUZE, G. Conversações. Tradução de Peter PálPelbart. São Paulo: Editora 34, 2010.

DELEUZE, G.; GUATTARI, F. O que é a filosofia? Rio de Janeiro: Editora 34, 2000.

DELEUZE, G.; GUATTARI, F. Mil platôs - capitalismo e esquizofrenia. v. 4. São Paulo: Ed. $54,1997$.

MACHADO, R. Deleuze, a arte e a filosofia. Rio de Janeiro: Zahar, 2009.

FERNANDES, N. M. G. Imagens cinematográficas no cineclube como máquina de guerra: movimentos de pensamentos e criações curriculares. Dissertação (Mestrado em Educação). UFES. Vitória, 2019.

ROLNIK, S. Esferas da insurreição: notas para uma vida não cafetinada. São Paulo: n1 edições, 2018.

SILVA, S. K.; DELBONI, T. M. Z. G. F. As imagens-tempo como dispositivos para fazer a língua gaguejar na produção do currículoescola. In: CARVALHO, J. M. (org.). Cinema e formação de professores e currículos e... Curitiba: Editora CRV, p. 23-33. 2017.

ZOUAIN, A. C. S. Crianças cineastas e seus roteiros criarteiros: infâncias, currículos e docências inventivas. Dissertação (Mestrado em Educação). UFES. Vitória, 2019. 
i Professora Adjunta II, vinculada ao Departamento de Teorias e Práticas de Ensino da Universidade Federal do Espírito Santo. Professora do Programa de Pós Graduação em Educação (PPGE/Ufes) e do Programa de Pós-Graduação Mestrado Profissional em Educação da Universidade Federal do Espírito Santo (PPGMPE/Ufes). Pós-doutora em Educação na linha de pesquisa em Currículos e Culturas do Programa de Pós-Graduação em Educação-Conhecimento e Inclusão Social, da FaE/UFMG. Doutorado em Educação pela Universidade Federal do Espírito Santo (Ufes), na linha de pesquisa "Cultura, Currículo e Formação de Educadores". Pesquisadora do Grupo de Pesquisa do CNPq "Com-versações com a filosofia da diferença em currículos e conversações de professores" (PPGE/Ufes), do Grupo de Pesquisa "Cotidiano Escolar e Currículo" (Proped/Uerj) e do Grupo de Estudos e Pesquisas sobre Currículos e Culturas (GECC), da FAE/UFMG.

ii Mestre em Educação pelo Programa de Pós-Graduação de Mestrado Profissional em Educação da Universidade Federal do Espírito Santo - PPGMPE/UFES. Membro do Grupo de Pesquisa do CNPq Com-versações com a Filosofia da Diferença em Currículos e Formação de Professores, UFES. Professora de Educação Infantil da Prefeitura Municipal de Vitória ES.

iii Mestre em Educação pelo Programa de Pós-Graduação de Mestrado Profissional em Educação da Universidade Federal do Espírito Santo - PPGMPE/UFES. Membro do Grupo de Pesquisa do CNPq Com-versações com a Filosofia da Diferença em Currículos e Formação de Professores, PPGE/UFES. Professor de Geografia, SEDU/ES.

Como citar esse artigo:

SILVA, Sandra Kretli; ZOUAIN, Ana Cláudia Santiago; FERNANDES, Nathan Moretto Guzzo. O cinema abrindo alas para as aprendências no cotidiano escolar. Revista Digital do LAV, Santa Maria: UFSM, v. 14, n. 2, p. 229-246, mai./ago. 2021. 